Review

\title{
Clinical significance of circulating tumor cells in gastric cancer patients
}

\author{
Jitao Zhou ${ }^{1, *}$, Xin Ma ${ }^{1, *}$, Feng $\mathrm{Bi}^{1}$ and Ming Liu ${ }^{1}$ \\ ${ }^{1}$ Department of Medical Oncology/Laboratory of Signal Transduction \& Molecular Targeted Therapy, West China Hospital, \\ Sichuan University, Chengdu, Sichuan, China \\ * These authors have contributed equally to this work
}

Correspondence to: Ming Liv, email: mingliu721@aliyun.com

Keywords: CTC; gastric cancer; EMT; Cellsearch; cancer metastasis

Received: August 29, $2016 \quad$ Accepted: January 16, $2017 \quad$ Published: January 28, 2017

Copyright: Zhou et al. This is an open-access article distributed under the terms of the Creative Commons Attribution License (CC-BY), which permits unrestricted use, distribution, and reproduction in any medium, provided the original author and source are credited.

\section{ABSTRACT}

Circulating tumor cells (CTCs) are rare cancer cells released from tumors into the blood stream that are thought to have a key role in cancer metastasis. Investigation of CTCs is an exciting area of research but remains in its infancy, and the presence of CTCs has been associated with worse prognosis in several major cancer types. Gastric cancer (GC) is a highly lethal malignancy and a serious public health concern in East Asia especially in China. There is an urgent need for identifying new, better prognostic markers to enhance diagnosis and prognosis, facilitate drug development, and to improve the treatment of gastric cancer patients. There are considerable interests in gastric CTCs given their potential use as gastric cancer biomarkers. This review highlights recent advances in studies of gastric CTCS, including the isolation and biological molecular characteristics of gastric CTCs, and their clinical significance.

\section{INTRODUCTION}

Gastric cancer (GC) is a highly lethal malignancy and a serious public health concern in East Asia, Eastern Europe, Central and South America. It was the fourth most common cancer ( 950000 new cases per year) and the third leading cause of cancer death all around the world in 2012 (GLOBOCAN 2012) [1]. Despite recent improvement in diagnosis and therapeutic methods, the 5-year survival rate is still less than $30 \%$ [2]. Approximately $50 \%$ of GC patients suffer from tumor recurrence or metastasis after curative resection [3]. For the patients diagnosed with advanced gastric cancer (AGC), chemotherapy and target therapy are mainstays of treatment. Unfortunately, more than $40 \%$ patients with AGC have no response to chemotherapy and the others would acquire chemoresistance soon, which leads to both poor survival and limited therapeutic options [4]. Therefore, there is an urgent need for identifying new, better prognostic markers to facilitate the diagnosis, improve the prediction of relapse and metastasis, and to predict the prognosis and determine the therapeutic responsiveness in AGC patients.

Disseminated tumor cells in the peripheral blood of cancer patients are known as circulating tumor cells
(CTCs). CTCs were first identified by Thomas Ashworth in 1869 [5]. However, the CTC research has been hampered by the technical difficulties to detect these rare cells. It was not until decades later that numerous new approaches were established to isolate, enumerate, and characterize CTCs in patients with various cancers [6]. CTCs have attracted more and more attention not only because of their easy accessibility but also their superiority over common tumor markers. CTCs represent both the phenotypic and genetic compositions of primary and metastatic tumors. Recent studies have shown that CTCs can be found in many solid tumor types such as lung, breast, renal, bladder, head and neck, and colorectal cancers [7-16]. In some of the solid cancers, enumeration of CTCs has served as surrogate markers for overall survival (OS), risk of relapse, progression-free survival (PFS) and chemotherapy effectiveness [7-17]. The most recent efforts have focused on haematological spread, epithelial-mesenchymal transition (EMT), cellular cooperation, circulating tumour microemboli (CTM) and the tumor-initiating capability of CTCs [18-25].

The aims of this review are to provide a comprehensive overview on the studies of CTCs in GC, including the biology, detection methods, and the clinical 
significance of CTCs in GC patients, discuss challenges facing the field, and to elaborate future prospects.

\section{DETECTION OF CTCS IN PATIENTS WITH GC}

CTCs have been detected in the blood of cancer patients at a very low concentration of 1 cell per $5 \times 10^{9}$

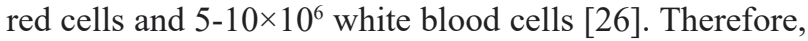
extremely sensitive and specific methods are required for detecting and enumerating CTCs generated by various malignancies including GC [17]. Generally, CTCs detection is a two-step procedure: first enrichment and then detection [27]. The enrichment step includes morphologic-based isolation and immune-magnetic selection (e.g. magnetic affinity cell sorting or magnetic beads enrichment) [28]. The enrichment step captures CTCs without labelling, using properties such as density (gradient centrifugation), cell size (membrane filters), electric charge (dielectrophoresis) and deform ability (microfluidic system in a chip) [29-32]. The detection step includes using either nucleic acid-based assays (reverse transcription polymerase chain reaction, RT-PCR) or cell recognition-based assays.

In the early days, only RT-PCR was used to identify and detect CTCs [33-34]. Identification of appropriate markers expressed by CTCs is critical to enhance the specificity and reliability of its detection. Conventional markers such as CKs and CEA mRNA were most used to detect CTCs in GC patients [35-37]. However, these tumor markers are expressed in normal peripheral blood cells and epithelial cells. Thus, some new biomarkers expressed in CTCs such as survivin and B7-H3 have been found to better predict tumor progression or prognosis in gastric cancer patients [38-40]. Multiple markers have been used to avoid false positive detection and increase detection rate. The detection of c-Met or MUC1 mRNA may be a promising tool for early detection of micrometastatic CTCs in GC patients [41]. The combination of four markers (human telomerase reverse transcriptase (TERT), cytokeratin 19 (CK19), CEA and MUC1) serves as a prognostic indicator for postoperative recurrence/ metastasis and overall survival in GC [42]. In general speaking, RT-PCR is highly sensitive, reproducible and economically feasible. But the specificity of this method is hindered by incalculability of CTCs and high false positive rates due to illegitimate marker expression by normal cells [43-44].

Cell-recognition based assays represent a major advancement in detecting CTCs. After the enrichment step, CTCs are detected using immunocytometric assays, such as immunocytochemistry, immunofluorescence and flow cytometry [45]. Comparing to RT-PCR, cell-recognition based assays allow enumeration of CTCs, morphological analysis of stained cells and molecular characterization of extracted cells [46]. Recently, the CellSearch system has been approved by U.S.FDA for CTC enumeration to improve prognosis and treatment efficacy in breast, colorectal and prostate cancer [47-49]. The platform is a semi-automated methodology able to detect and enumerate CTCs. $7.5 \mathrm{ml}$ of whole blood is mixed with magnetic iron nanoparticles coated with anti-EpCAM antibody. Then EpCAM positive cells are stained with anti-CK and antiCD45 fluorescent antibodies to detect epithelial cells and to exclude leukocytes, respectively. DAPI nuclear dye (4',6-diamidino-2-phenylindole) is used to allow microscopic identification of relevant cell fraction. CTCs are identified as $\mathrm{CK}^{+} \mathrm{DAPI}^{+} \mathrm{CD} 45$. By using this method, a number of studies have reported the role of CTCs in GC patients.

Alternative approaches are in development to improve detection rate by isolating CTCs with high purity. One such approach is called CTC-chip consisting of an array of antibody (EpCAM)-coated microposts and has successfully identified CTCs in the peripheral blood of patients with metastatic lung, prostate, pancreatic, breast and colon cancer samples [50]. Another approach is called "Herringbone-chip" created by the same research team using herringbone grooves within the transparent wall of the device allowing for higher blood volume throughput and increases CTC capture efficiency and purity [51].

\section{BIOLOGY OF CTCS IN PATIENTS WITH GC}

Recently emerging evidences suggest that there is considerable heterogeneity in CTC populations. This feature of CTCs has potential of informing intra-tumor heterogeneity and tumor evolution and thus has attracted more and more attention of research community [27, 52].

\section{Circulating gastric cancer stem cells}

A subset of cancer cells are thought to have the properties of adult stem cells (self-renewal and multipotency) and are capable of initiating tumor growth. These cells have been named as 'cancer stem cells' or 'tumor-initiating cells'. CTCs with stem celllike characteristics might play a crucial role in breast cancer metastasis [53-54]. CD44 has been identified as a marker of gastric cancer stem cells [55]. In a prospective study of 45 GC patients, nineteen CTC-positive patients had CD44-positive CTCs, and they were more likely to develop metastasis and recurrence than patients with CD44-negative CTCs. Moreover, the mean time to recurrence was shorter in patients with CD44-positive CTCs. Thus, CD44 positivity in CTCs might serve as a novel marker for predicting metastasis and recurrence risk for GC patients [56-57]. Consistent with this notion, our group has found that compared to CD44/CD45- gastric CTCs, $\mathrm{CD} 44^{+} / \mathrm{CD} 45^{-}$gastric CTCs have stronger colony 
Table 1: Summary of relevant results from CTC studies in gastric cancer by CellSearch.

\begin{tabular}{|c|c|c|c|c|}
\hline $\begin{array}{l}\text { Characteristic and number of } \\
\text { patients }\end{array}$ & Detection rate & $\begin{array}{l}\text { Positive } \\
\text { cutoff }\end{array}$ & Results & Ref. \\
\hline $\begin{array}{l}\text { Nonmetastatic } 14 \\
\text { Metastatic } 27 \\
\text { Post curative resection } 3\end{array}$ & $\begin{array}{l}14.3 \% \\
55.6 \% \\
0\end{array}$ & $\geq 2 \mathrm{CTCs}$ & $\begin{array}{l}\text { Correlated with advanced tumor stage, } \\
\text { peritoneal dissemination, shorter survival. } \\
\text { The change in CTCs correlate with disease } \\
\text { progression and chemotherapeutic effect. }\end{array}$ & Hiraiwa K [69] \\
\hline $\begin{array}{l}\text { Metastatic } 52 \\
\text { baseline } \\
2 \text { week } \\
4 \text { week }\end{array}$ & $\begin{array}{l}\text { nonPD vs PD } \\
19.2 \% \text { vs } 13.4 \% \\
0 \text { vs } 13.7 \% \\
2 \% \text { vs } 16.7 \%\end{array}$ & $\geq 4 \mathrm{CTCs}$ & $\begin{array}{l}\text { CTCs measurement may be useful as a } \\
\text { surrogate marker for determining response } \\
\text { to S-1 based or paclitaxel regimens in } \\
\text { advanced GC. }\end{array}$ & $\begin{array}{l}\text { Matsusaka S } \\
{[75]}\end{array}$ \\
\hline $\begin{array}{l}\text { Resection } 148 \\
\text { Nonresectable } 103\end{array}$ & $\begin{array}{l}60.2 \% \\
11.3 \%\end{array}$ & $\geq 1 \mathrm{CTCs}$ & $\begin{array}{l}\text { Predicting tumor progression, prognosis, } \\
\text { and the effect of chemotherapy in patients } \\
\text { with gastric cancer. }\end{array}$ & $\begin{array}{l}\text { Uenosono } \quad \mathrm{Y} \\
{[73]}\end{array}$ \\
\hline Advanced GC 136 & $18.4 \%$ & $\geq 1 \mathrm{CTCs}$ & $\begin{array}{l}\text { Independent predictor of a shorter PFS in } \\
\text { AGC. A valuable biomarker for selecting } \\
\text { patients required intensive treatment. }\end{array}$ & Okabe H [74] \\
\hline $\begin{array}{l}\text { Advanced GC } 136 \\
106 \text { evaluable Patients } \\
\text { baseline } \\
6 \text { week }\end{array}$ & $\begin{array}{l}41.9 \% \\
42.5 \% \\
24.5 \%\end{array}$ & $\geq 3 \mathrm{CTCs}$ & $\begin{array}{l}\text { Post-therapy CTC level evaluating } \\
\text { therapeutic response and predicting their } \\
\text { prognosis. Changes in CTCs following } \\
\text { therapy useful in rapidly identifying } \\
\text { ineffective treatments and poor prognosis. }\end{array}$ & Yilin Li [76] \\
\hline
\end{tabular}

GC: gastric cancer; PD: progression disease; CTCs: circulating tumor cells

formation ability and exhibit higher capacity of migration, invasion and resistance to irradiation, chemotherapy drugs and target drugs [58].

\section{GC CTCs and EMT}

Most cancer-related deaths are associated with metastasis. CTCs are known to be necessary but not sufficient for the initiation of metastasis. EMT is a multistep process that plays a key role in metastasis and cancer progression [59]. EMT is characterized by the downregulation of epithelial markers, such as EpCAM and CK, and the upregulation of mesenchymal markers, such as vimentin and twist. CTCs that have undergone EMT can escape the detection by the EpCAM-based enrichment technique like CellSearch system [60]. Although several studies explored mesenchymal markers (vimentin, N-cadherin, O-cadherin, twist, fibronectin and serpin peptidase inhibitor) to profile the EMT phenotype of CTCs, no defined marker or panel of markers have been identified [61].

$\mathrm{Li}$ et al [62] detected CTCs of $44 \mathrm{GC}$ patients for the expression of four epithelial $(\mathrm{E}+$ ) transcripts (keratins 8 , 18, and 19 and epithelial cell adhesion molecule) and two mesenchymal $(\mathrm{M}+)$ transcripts (Vimentin and Twist) by a quantifiable, dual-colorimetric RNA-in situ hybridization assay. CTCs had been captured in $35 \mathrm{GC}$ patients and EMT CTCs were identified in 14 patients with $\mathrm{M}+$ or $\mathrm{M}+>\mathrm{E}+$. Our group also found that epithelial markers pan-CK, E-cadherin were decreased, and mesenchymal markers N-cadherin, vimentin were overexpressed in gastric CTCs [63]. This EMT subgroup of CTCs in gastric cancer deserves more attention in the future.

\section{Molecular characterization of GC CTCs and target therapy}

Ideally, CTCs are used as a liquid biopsy to identify the molecular features of a patient's tumor. Then accordingly, the results may guide personalized treatment options. Some small sample studies have been carried out to verify this hypothesis [64-66]. For example, HER2 expression in CTCs of breast cancer has been evaluated. Interestingly, some breast cancer patients have discordant HER2 status for their CTCs (positive) and primary tumor (negative), but they still benefit from trastuzumab therapy [67-68].

Karyotyping and phenotyping of the enriched CTCs in therapeutic advanced GC patients were carried out by using the integrated subtraction enrichment (SET) and immunofluorescence staining in situ hybridization (iFISH) platform. CellSearch system was applied as a reference control. Phenotyping of CTCs in HER2 positive AGC patients demonstrated that HER2+ CTCs could be effectively eliminated in response to HER2-targeted therapy. Karyotyping of CTCs indicated that examination of the copy number of chromosome 8 in CTCs provides a potential approach for predicting chemotherapeutic efficacy and monitoring chemo-resistance [69]. However, the relevance of CTC heterogeneity in response to or 
in developing resistance to targeted therapy is yet to be unveiled. More well-designed and prospective randomized studies assessing the predictive value of CTCs are needed.

\section{CLINICALUTILITYOFCTCSINPATIENTS WITH GC}

The detection of CTCs in peripheral blood has received growing enthusiasm in the clinical utility of various cancers. Since 1990s many studies have been performed to indicate the correlation between CTCs and the clinicopathological characteristics of gastric tumor [33-42, 69-71]. These studies suggest that CTCs may play a role in predicting tumor prognosis and response to treatment. However, these studies used a variety of methods for CTC detection. Tang et al [72] have performed a meta-analysis of the diagnostic accuracy of various CTCs detection methods in gastric cancer and found that results vary among different detection methods. They believe that a solid conclusion could be drawn with the development of new detection technologies.

To date, the CellSearch system is the only CTCs detecting technique approved by the U.S.FDA. It is possible to obtain highly reproducible quantitative results from different laboratories by using this detection platform. CTC numbers as quantified by the CellSearch procedure have been shown to have prognostic significance, predicting chemotherapy effectiveness in patients with various types of carcinomas (e.g. breast cancer, prostate cancer and colorectal cancer) [7-11]. The current review will focus on studies reporting significant data about the role of CTCs in gastric cancer obtained by the CellSearch system (Table 1).

Measurement of CTCs in GC patients could be useful for judging tumor stage and predicting patients' survival. Yoshikazu et al [73] performed a prospective study to evaluate CTCs in $251 \mathrm{GC}$ patients and explored the clinical impact of CTCs using the CellSearch system. CTCs were detected in 16 patients $(10.8 \%)$ from the resection group with a significantly higher relapse rate, in 62 patients $(60.2 \%)$ from the nonresectable group but not detected in healthy volunteers. Furthermore, CTCs in patients who underwent gastrectomy were significantly correlated with the depth of tumor invasion, lymph node metastasis, distant metastasis, disease stage, vessel invasion, and lymphatic invasion. Consistent with the above, the overall survival rate of the entire cohort with CTCs was significantly lower than that of patients without CTCs. Hiraiwa et al [69] performed a similar study enrolled with 130 gastrointestinal cancer patients and 41 healthy volunteers, including 44 gastric cancer patients. CTC counts were larger in 27 metastatic GC patients than that in 14 non-metastatic patients. Another study including 136 patients with AGC suggests that emergence of CTCs is an independent predictor of a shorter PFS [74]. Thus, evaluation of CTCs may be a useful strategy for predicting tumor progression and prognosis in patients with GC.

Besides being as diagnostic and prognostic indicators, CTCs hold promise to be biomarkers to aid in treatment selection. The detection of CTCs in the peripheral blood of patients with AGC has been reported to predict efficacy of chemotherapy treatment. In another study, CTCs of whole blood at baseline, 2 weeks, and 4 weeks were detected in 52 patients with AGC treated with S-1-based regimen (S-1 with or without cisplatin) or paclitaxel. Patients with $\geq 4$ CTCs at 2-week and 4-week points had much shorter PFS and OS than those with $<$ 4 CTCs [75.] A single-centre, prospective study was undertaken in $136 \mathrm{AGC}$ patients and their CTCs were enumerated at baseline and at the first response evaluation. Following 6 weeks of chemotherapy, the elevated CTCs may correspond with an ineffective therapeutic response and independently predict a shorter PFS and OS [76]. Monitoring dynamic changes of CTCs in response to therapy may be a useful alternative for assessing treatment resistance.

Measurement of CTCs may be a useful diagnostic tool to predict pleural dissemination which is difficult to detect in current imaging studies, such as computed tomography, ultrasonography and positron emission tomography. Breast cancer, prostate cancer or colorectal cancer patients who have hematogenous metastasis seem to have a high incidence of CTCs. However, by the CellSearch system, CTCs were detected more often in $\mathrm{GC}$ patients with peritoneal metastasis(PM)compared to GC patients with hematogenous metastasis [74]. The underlying mechanism remains unclear. Considering that detection of CTCs by the CellSearch system is based on isolation and enumeration of cells expressing EpCAM, EpCAM appears to play an important role in peritoneal metastasis (PM). Imano et al [77] have found that all of 35 PM specimens showed overexpression of EpCAM. Thus they postulate that only GC cells expressing a high level of EpCAM might metastasize to the peritoneum. Meanwhile, the EpCAM antibody has been reported to be a therapeutic agent in patients with malignant ascites in several types of carcinoma [78].

\section{PERSPECTIVES}

In summary, the science of CTCs is an exciting area of research but remains in its infancy. The translation of CTC research to a routine clinical test is hurdled by the lack of consensus in technical approaches. The CellSearch system is the first standard semi-automated methodology approved by U.S.FDA to detect and enumerate CTCs. A number of studies have reported that enumeration of CTCs using the CellSearch system could serve as an indicator of prognosis and treatment efficacy in various cancers, such as breast, colorectal and prostate cancers. Recently, several studies reported that measurement of CTCs with the CellSearch in GC patients could be utilized for judging 
tumor stage, predicting patients' survival and evaluating therapeutic response. However, large-scale clinical trials would be desirable for further validating the significant role of CTCs in GC patients and for determining the proper cutoff of positive CTCs score for GC patients.

CTCs are now defined to be a group of heterogeneous cells and have been suggested to have great potential for personalized therapy selection. This will be the key direction in CTCs research field. More studies are still needed to understand the CTC biology and determine the biomarkers of different subgroup of CTCs (e.g. EMT transition cells, stem cells). The CellSearch technology has limitation in detecting EMT CTCs. Novel revolutionary approaches must have increased sensitivity to accommodate CTC heterogeneity and need to be assessed in clinical trials to gain a position in clinical practice.

\section{Abbreviations}

CTC, Circulating Tumor Cells; GC, Gastric Cancer; AGC, Advanced Gastric Cancer; EMT, EpithelialMesenchymal Transition; CTM, Circulating Tumour Microemboli; OS, Overall Survival; PFS, ProgressionFree Survival; HER2, Human Epidermal Growth Factor Receptor 2.

\section{ACKNOWLEDGMENTS}

This work was supported by National Natural Science Foundation of China (Grant No. 81572850 $\& 81502655)$.

\section{CONFLICTS OF INTEREST}

Authors declare no conflict of interest for this article.

\section{REFERENCES}

1. Ferlay J, Soerjomataram I, Dikshit R, Eser S, Mathers C, Rebelo M, Parkin DM, Forman D, Bray F. Cancer incidence and mortality worldwide: sources, methods and major patterns in GLOBOCAN 2012. Int J Cancer. 2015; 136: E359-E386.

2. Correia M, Machado JC, Ristimäki A. Basic aspects of gastric cancer. Helicobacter. 2009; 14 Suppl 1:36-40.

3. Marrelli D, De Stefano A, de Manzoni G, Morgagni P, Di Leo A, Roviello F. Prediction of recurrence after radical surgery for gastric cancer: a scoring system obtained from a prospective multicenter study. Ann Surg. 2005; 241:247255.

4. Hartgrink HH, Jansen EPM, van Grieken NCT, van de Velde CJH. Gastric cancer. The Lancet. 2009; 374: 477490 .
5. Ashworth TR. A case of cancer in which cells similar to those in the tumours were seen in the blood after death. Aust Med J. 1869; 14:146-147.

6. Pantel K, Brakenhoff RH. Dissecting the metastatic cascade. Nat Rev Cancer. 2004; 4:448-56.

7. Cristofanilli M, Budd GT, Ellis MJ, Stopeck A, Matera J, Miller MC, Reuben JM, Doyle GV, Allard WJ, Terstappen LW, Hayes DF. Circulating tumor cells, disease progression, and survival in metastatic breast cancer. $\mathrm{N}$ Engl J Med. 2004; 351:781-91.

8. Budd GT, Cristofanilli M, Ellis MJ, Stopeck A, Borden E, Miller MC, Matera J, Repollet M, Doyle GV, Terstappen LW, Hayes DF. Circulating tumor cells versus imaging predicting overall survival in metastatic breast cancer. Clin Cancer Res. 2006; 12:6403-9.

9. Cristofanilli M, Hayes DF, Budd GT, Ellis MJ, Stopeck A, Reuben JM, Doyle GV, Matera J, Allard WJ, Miller MC, Fritsche HA, Hortobagyi GN, Terstappen LW. Circulating tumor cells: a novel prognostic factor for newly diagnosed metastatic breast cancer. J Clin Oncol. 2005; 23:1420-30.

10. Cohen SJ, Punt CJ, Iannotti N, Saidman BH, Sabbath KD, Gabrail NY, Picus J, Morse M, Mitchell E, Miller MC, Doyle GV, Tissing H, Terstappen LW, et al. Relationship of circulating tumor cells to tumor response, progressionfree survival, and overall survival in patients with metastatic colorectal cancer. J Clin Oncol. 2008; 26:3213-3221.

11. Bono JS, Scher HI, Montgomery RB, Parker C, Miller MC, Tissing H, Doyle GV, Terstappen LW, Pienta KJ, Raghavan D. Circulating tumor cells predict survival benefit from treatment in metastatic castration-resistant prostate cancer. Clin Cancer Res. 2008; 14:6302-9.

12. Hiltermann TJ, Pore MM, van den Berg A, Timens W, Boezen HM, Liesker JJ, Schouwink JH, Wijnands WJ, Kerner GS, Kruyt FA, Tissing H, Tibbe AG, Terstappen LW, et al. Circulating tumor cells in small-cell lung cancer: a predictive and prognostic factor. Ann Oncol. 2012; 23:2937-42.

13. Truini A, Alama A, Dal Bello MG, Coco S, Vanni I, Rijavec E, Genova C, Barletta G, Biello F, Grossi F. Clinical Applications of Circulating Tumor Cells in Lung Cancer Patients by CellSearch System. Front Oncol. 2014; $4: 242$.

14. Rossi E, Fassan M, Aieta M, Zilio F, Celadin R, Borin M, Grassi A, Troiani L, Basso U, Barile C, Sava T, Lanza C, Miatello L, et al. Dynamic changes of live/apoptotic circulating tumour cells as predictive marker of response to sunitinib in metastatic renal cancer. Br J Cancer. 2012; 107:1286-94.

15. Msaouel P, Koutsilieris M. Diagnostic value of circulating tumor cell detection in bladder and urothelial cancer: systematic review and meta- analysis. BMC Cancer. 2011; 11:336.

16. Nichols AC, Lowes LE, Szeto CC, Basmaji J, Dhaliwal S, Chapeskie C, Todorovic B, Read N, Venkatesan V, 
Hammond A, Palma DA, Winquist E, Ernst S, et al. Detection of circulating tumor cells in advanced head and neck cancer using the cellsearch system. Head Neck. 2012; 34:1440-4.

17. Chambers AF, Groom AC, MacDonald IC. Dissemination and growth of cancer cells in metastatic sites. Nat Rev Cancer. 2002; 2:563-72.

18. Baccelli I, Schneeweiss A, Riethdorf S, Stenzinger A, Schillert A, Vogel V, Klein C, Saini M, Bäuerle T, Wallwiener M, Holland-Letz T, Höfner T, Sprick M, et al. Identification of a population of blood circulating tumor cells from breast cancer patients that initiates metastasis in a xenograft assay. Nat Biotechnol. 2013; 31:539-44.

19. Zhang L, Ridgway LD, Wetzel MD, Ngo J, Yin W, Kumar D, Goodman JC, Groves MD, Marchetti D. The identification and characterization of breast cancer CTCs competent for brain metastasis. Sci Transl Med. 2013; 5:180ra48

20. Onstenk W, Sieuwerts AM, Mostert B, Lalmahomed Z, Bolt-de Vries JB, van Galen A, Smid M, Kraan J, Van M, de Weerd V, Ramírez-Moreno R, Biermann K, Verhoef C, et al. Molecular characteristics of circulating tumor cells resemble the liver metastasis more closely than the primary tumor in metastatic colorectal cancer. Oncotarget. 2016; 7:59058-59069. doi: 10.18632/oncotarget.10175.

21. Thiery JP, Lim CT. Tumor dissemination: an EMT affair. Cancer Cell. 2013; 23:272-3.

22. Tsuji T, Ibaragi S, Hu GF. Epithelial-mesenchymal transition and cell cooperativity in metastasis. Cancer Res. 2009; 69:7135-9.

23. Calbo J, van Montfort E, Proost N, van Drunen E, Beverloo HB, Meuwissen R, Berns A. A functional role for tumor cell heterogeneity in a mouse model of small cell lung cancer. Cancer Cell. 2011; 19:244-56.

24. Duda DG, Duyverman AM, Kohno M, Snuderl M, Steller EJ, Fukumura D, Jain RK. Malignant cells facilitate lung metastasis by bringing their own soil. Proc Natl Acad Sci U S A. 2010; 107:21677-82.

25. Friedl P, Noble PB, Walton PA, Laird DW, Chauvin PJ, Tabah RJ, Black M, Zänker KS. Migration of coordinated cell clusters in mesenchymal and epithelial cancer explants

26. Allard WJ, Matera J, Miller MC, Repollet M, Connelly MC, Rao C, Tibbe AG, Uhr JW, Terstappen LW. Tumor cells circulate in the peripheral blood of all major carcinomas but not in healthy subjects or patients with nonmalignant diseases. Clin Cancer Res. 2004; 10:6897-904.

27. Alix-Panabières $C$, Pantel K. Circulating tumor cells: liquid biopsy of cancer. Clin Chem. 2013; 59:110-8.

28. Talasaz AH, Powell AA, Huber DE, Berbee JG, Roh KH, Yu W, Xiao W, Davis MM, Pease RF, Mindrinos MN, Jeffrey SS, Davis RW. Isolating highly enriched populations of circulating epithelial cells and other rare cells from blood using a magnetic sweeper device. Proc Natl Acad Sci U S
A. $2009 ; 106: 3970-5$.

29. Vona G, Sabile A, Louha M, Sitruk V, Romana S, Schütze K, Capron F, Franco D, Pazzagli M, Vekemans M, Lacour B, Bréchot C, Paterlini-Bréchot P. Isolation by size of epithelial tumor cells: a new method for the immunomorphological and molecular characterization of circulating tumor cells. Am J Pathol. 2000; 156:57-63.

30. Gascoyne PR, Noshari J, Anderson TJ, Becker FF. Isolation of rare cells from cell mixtures by dielectrophoresis. Electrophoresis. 2009; 30:1388-98.

31. Moon HS, Kwon K, Kim S, Han H, Sohn J, Lee S, Jung H. Continuous separation of breast cancer cells from blood samples using multi-orifice flow fractionation (MOFF) and dielectrophoresis (DEP). Lab Chip. 2011; 11:1118-1125.

32. Nagrath S, Sequist LV, Maheswaran S, Bell DW, Irimia D, Ulkus L, Smith MR, Kwak EL, Digumarthy S, Muzikansky A, Ryan P, Balis UJ, Tompkins RG, et al. Isolation of rare circulating tumour cells in cancer patients by microchip technology. Nature. 2007; 450:1235-1239.

33. Okada Y, Fujiwara Y, Yamamoto H, Sugita Y, Yasuda T, Doki Y, Tamura S, Yano M, Shiozaki H, Matsuura $\mathrm{N}$, Monden $\mathrm{M}$. Genetic detection of lymph node micrometastasis in patients with gastric carcinoma by multiple-marker reverse transcriptase-polymerase chain reaction assay. Cancer. 2001; 92: 2056-64.

34. Kodera Y, Nakanishi H, Ito S, Yamamura Y, Kanemitsu Y, Shimizu Y, Hirai T, Yasui K, Kato T, Tatematsu M. Quantitative detection of disseminated free cancer cells in peritoneal washes with real-time reverse transcriptasepolymerase chain reaction. A sensitive predictor of outcome for patients with gastric carcinoma. Ann Surg. 2002; 235:499-506.

35. Huang P, Wang J, Guo Y, Xie W. Molecular detection of disseminated tumor cells in the peripheral blood in patients with gastrointestinal cancer. J Cancer Res Clin Oncol. 2003; 129:192-198.

36. Fujita Y, Terashima M, Hoshino Y, Ohtani S, Kashimura S, Kanzaki N, Osuka F, Kogure M, Gotoh M. Detection of cancer cells disseminated in bone marrow using real-time quantitative RT- PCR of CEA, CK19, and CK20 mRNA in patients with gastric cancer. Gastric Cancer. 2006; 9:308314.

37. Ishigami S, Sakamoto A, Uenosono Y, Nakajo A, Okumura H, Matsumoto M, Setoyama T, Arigami T, Uchikado Y, Arima H, Natsugoe S, Aikou T. Carcinoembryonic antigen messenger RNA expression in blood can predict relapse in gastric cancer. J Surg Res. 2008; 148:205-209.

38. Arigami T, Uenosono $\mathrm{Y}$, Hirata $\mathrm{M}$, Yanagita S, Ishigami S, Natsugoe S. B7-H3 expression in gastric cancer: a novel molecular blood marker for detecting circulating tumor cells. Cancer Sci. 2011; 102:1019-24.

39. Cao W, Yang W, Li H, Lou G, Jiang J, Geng M, Xi W, Ren R, Qu Q, Jin X, Zhu Y, Jin Y. Using detection of survivinexpressing circulating tumor cells in peripheral blood to 
predict tumor recurrence following curative resection of gastric cancer. J Surg Oncol. 2010; 103:110-5.

40. Yie SM, Lou B, Ye SR, Cao M, He X, Li P, Hu K, Rao L, Wu SM, Xiao HB, Gao E. Detection of survivin-expressing circulating cancer cells (CCCs) in peripheral blood of patients with gastric and colorectal cancer reveals high risks of relapse. Ann Surg Oncol. 2008; 15:3073-82.

41. Uen YH, Lin SR, Wu CH, Hsieh JS, Lu CY, Yu FJ, Huang TJ, Wang JY. Clinical significance of MUC1 and c-Met RT-PCR detection of circulating tumor cells in patients with gastric carcinoma. Clin Chim Acta. 2006; 367:55-61.

42. Wu CH1, Lin SR, Yu FJ, Wu DC, Pan YS, Hsieh JS, Huang SY, Wang JY. Development of a high-throughput membrane-array method for molecular diagnosis of circulating tumor cells in patients with gastric cancers. Int J Cancer. 2006; 119: 373-379.

43. Lambrechts AC, Bosma AJ, Klaver SG, Top B, Perebolte L, van' t Veer LJ, Rodenhuis S. Comparison of immunocytochemistry, reverse transcriptase polymerase chain reaction, and nucleic acid sequence-based amplification for the detection of circulating breast cancer cells. Breast Cancer Res Treat. 1999; 56:219-31.

44. Wicha MS, Hayes DF. Circulating tumor cells: not all detected cells are bad and not all bad cells are detected. J Clin Oncol. 2011; 29: 1508-1511.

45. Alunni-Fabbroni M, Sandri MT. Circulating tumor cells in clinical practice. Methods of detection and possible characterization. Methods. 2010; 50:289-97.

46. Mostert B, Sleijfer S, Foekens JA, Gratama JW. Circulating tumor cells: detection methods and their clinical relevance in breast cancer. Cancer Treat Rev. 2009; 35:463-74.

47. Cristofanilli M1, Budd GT, Ellis MJ, Stopeck A, Matera J, Miller MC, Reuben JM, Doyle GV, Allard WJ, Terstappen LW, Hayes DF. Circulating tumor cells, disease progression, and survival in metastatic breast cancer. $\mathrm{N}$ Engl J Med. 2004; 351:781-91.

48. Cohen SJ, Alpaugh RK, Gross S, O’Hara SM, Smirnov DA, Terstappen LW, Allard WJ, Bilbee M, Cheng JD, Hoffman JP, Lewis NL, Pellegrino A, Rogatko A, et al. Isolation and characterization of circulating tumor cells in patients with metastatic colorectal cancer. Clin Colorectal Cancer. 2006; 6:125-32.

49. Okegawa T, Nutahara K, Higashihara E. Prognostic significance of circulating tumor cells in patients with hormone refractory prostate cancer. J Urol. 2009: 181:1091-7.

50. Nagrath S, Sequist LV, Maheswaran S, Bell DW, Irimia D, Ulkus L, Smith MR, Kwak EL, Digumarthy S, Muzikansky A, Ryan P, Balis UJ, Tompkins RG, et al. Isolation of rare circulating tumour cells in cancer patients by microchip technology. Nature. 2007; 450:1235-9.

51. Stott SL, Hsu CH, Tsukrov DI, Yu M, Miyamoto DT, Waltman BA, Rothenberg SM, Shah AM, Smas ME, Korir GK, Floyd FP Jr, Gilman AJ, Lord JB, et al. Isolation of circulating tumor cells using a microvortex-generating herringbone-chip. Proc Natl Acad Sci U S A. 2010; 107:18392-7.

52. Kang Y, Pantel K. Tumor cell dissemination: emerging biological insights from animal models and cancer patients. Cancer Cell. 2013; 23: 573-581.

53. Wang N, Shi L, Li H, Hu Y, Du W, Liu W, Zheng J, Huang $\mathrm{S}, \mathrm{Qu}$ X. Detection of circulating tumor cells and tumor stem cells in patients with breast cancer by using flow cytometry. Tumor Biology. 2012; 33:561-569.

54. Theodoropoulos PA, Polioudaki H, Agelaki S, Kallergi G, Saridaki Z, Mavroudis D, Georgoulias V. Circulating tumor cells with a putative stem cell phenotype in peripheral blood of patients with breast cancer. Cancer Letters. 2010; 288: 99-106.

55. Takaishi S, Okumura T, Tu S, Wang SS, Shibata W, Vigneshwaran R, Gordon SA, Shimada Y, Wang TC. Identification of gastric cancer stem cells using the cell surface marker CD44. Stem Cells. 2009; 27:1006-1020.

56. Li M, Zhang B, Zhang Z, Liu X, Qi X, Zhao J, Jiang Y, Zhai H, Ji Y, Luo D. Stem cell-like circulating tumor cells indicate poor prognosis in gastric cancer. Biomed Res Int. 2014; 2014:981261.

57. Toyoshima K, Hayashi A, Kashiwagi M, Hayashi N, Iwatsuki M, Ishimoto T, Baba Y, Baba H, Ohta Y. Analysis of circulating tumor cells derived from advanced gastric cancer. Int J Cancer. 2015; 137:991-8.

58. Yuan D, Chen L, Li M, Xia H, Zhang Y, Chen T, Xia R, Tang Q, Gao F, Mo X, Liu M, Bi F. Isolation and characterization of circulating tumor cells from human gastric cancer patients. J Cancer Res Clin Oncol. 2015; 141:647-60.

59. Thiery JP. Epithelial-mesenchymal transitions in tumour progression. Nat Rev Cancer. 2002; 2: 442- 454.

60. Yu M, Bardia A, Wittner BS, Stott SL, Smas ME, Ting DT, Isakoff SJ, Ciciliano JC, Wells MN, Shah AM, Concannon $\mathrm{KF}$, Donaldson MC, Sequist LV, et al. Circulating breast tumor cells exhibit dynamic changes in epithelial and mesenchymal composition. Science. 2013; 339: 580-584.

61. Satelli A, Brownlee Z, Mitra A, Meng QH, Li S. Circulating tumor cell enumeration with a combination of epithelial cell adhesion molecule- and cell-surface vimentin-based methods for monitoring breast cancer therapeutic response. Clin Chem. 2015; 61: 259-266.

62. Li TT, Liu H, Li FP, Hu YF, Mou TY, Lin T, Yu J, Zheng L, Li GX. Evaluation of epithelial-mesenchymal transitioned circulating tumor cells in patients with resectable gastric cancer: Relevance to therapy response. World J Gastroenterol. 2015; 21:13259-67.

63. Yuan D, Xia H, Zhang Y, Chen L, Leng W, Chen T, Chen Q, Tang Q, Mo X, Liu M, Bi F. P-Akt/miR-200 signaling regulates epithelial-mesenchymal transition, migration and invasion in circulating gastric tumor cells. Int J Oncol. 2014; 45:2430-8. 
64. Pailler E, Adam J, Barthélémy A, Oulhen M, Auger N, Valent A, Borget I, Planchard D, Taylor M, André F, Soria JC, Vielh P, Besse B, et al. Detection of circulating tumor cells harboring a unique ALK rearrangement in ALKpositive non-small-cell lung cancer. J Clin Oncol. 2013: 31:2273-2281.

65. Maheswaran S, Sequist LV, Nagrath S, Ulkus L, Brannigan $\mathrm{B}$, Collura CV, Inserra E, Diederichs S, Iafrate AJ, Bell DW, Digumarthy S, Muzikansky A, Irimia D, et al. Detection of mutations in EGFR in circulating lung-cancer cells. N Engl J Med. 2008; 359:366-377.

66. Camidge DR, Bang YJ, Kwak EL, Iafrate AJ, VarellaGarcia M, Fox SB, Riely GJ, Solomon B, Ou SH, Kim DW, Salgia R, Fidias P, Engelman JA, et al. Activity and safety of crizotinib in patients with ALK-positive non-small-cell lung cancer: updated results from a phase 1 study. Lancet Oncol. 2012; 13:1011-1019.

67. Hayes DF, Walker TM, Singh B, Vitetta ES, Uhr JW, Gross S, Rao C, Doyle GV, Terstappen LW. Monitoring expression of HER-2 on circulating epithelial cells in patients with advanced breast cancer. Int J Oncol. 2002; 21:1111-1117.

68. Liu Y, Liu Q, Wang T, Bian L, Zhang S, Hu H, Li S, $\mathrm{Hu} \mathrm{Z}, \mathrm{Wu} \mathrm{S}$, Liu B, Jiang Z. Circulating tumor cells in HER2-positive metastatic breast cancer patients:a valuable prognostic and predictive biomarker. BMC Cancer. 2013, 13:202.

69. Hiraiwa K, Takeuchi H, Hasegawa H, Saikawa Y, Suda K, Ando T, Kumagai K, Irino T, Yoshikawa T, Matsuda S, Kitajima M, Kitagawa Y. Clinical significance of circulating tumor cells in blood from patients with gastrointestinal cancers. Ann Surg Oncol. 2008; 15:3092-3100.

70. Aihara T, Noguchi S, Ishikawa O, Furukawa H, Hiratsuka M, Ohigashi H, Nakamori S, Monden M, Imaoka S: Detection of pancreatic and gastric cancer cells in peripheral and portal blood by amplification of keratin 19 mRNA with reverse transcriptase-polymerase chain reaction. Int J Cancer. 1997; 72:408-411.

71. Lurje G, Schiesser M, Claudius A, Schneider PM. Circulating tumor cells in gastrointestinal malignancies: current techniques and clinical implications. J Oncol. 2010; 2010:392652.
72. Tang L, Zhao S, Liu W, Parchim NF, Huang J, Tang Y, Gan $\mathrm{P}$, Zhong M. Diagnostic accuracy of circulating tumor cells detection in gastric cancer: systematic review and metaanalysis. BMC Cancer. 2013; 13:314.

73. Uenosono Y, Arigami T, Kozono T, Yanagita S, Hagihara T, Haraguchi N, Matsushita D, Hirata M, Arima H, Funasako Y, Kijima Y, Nakajo A, Okumura H, et al. Clinical significance of circulating tumor cells in peripheral blood from patients with gastric cancer. Cancer. 2013; 119:3984-91.

74. Okabe H, Tsunoda S, Hosogi H, Hisamori S, Tanaka E, Tanaka S, Sakai Y. Circulating Tumor Cells as an Independent Predictor of Survival in Advanced Gastric Cancer. Ann Surg Oncol. 2015; 22:3954-61.

75. Matsusaka S, Chìn K, Ogura M, Suenaga M, Shinozaki E, Mishima Y, Terui Y, Mizunuma N, Hatake K. Circulating tumor cells as a surrogate marker for determining response to chemotherapy in patients with advanced gastric cancer. Cancer Sci. 2010; 101:1067-71.

76. Li Y, Gong J, Zhang Q, Lu Z, Gao J, Li Y, Cao Y, Shen L. Dynamic monitoring of circulating tumour cells to evaluate therapeutic efficacy in advanced gastric cancer. Br J Cancer. 2016; 114:138-45.

77. Imano M, Itoh T, Satou T, Yasuda A, Nishiki K, Kato H, Shiraishi O, Peng YF, Shinkai M, Tsubaki M, Yasuda T, Imamoto $\mathrm{H}$, Nishida $\mathrm{S}$, et al. High expression of epithelial cellular adhesion molecule in peritoneal metastasis of gastric cancer. Target Oncol. 2013; 8:231-5.

78. Burges A, Wimberger P, Kümper C, Gorbounova V, Sommer H, Schmalfeldt B, Pfisterer J, Lichinitser M, Makhson A, Moiseyenko V, Lahr A, Schulze E, Jäger M, et al. Effective relief of malignant ascites in patients with advanced ovarian cancer by a trifunctional anti-EpCAM 9 anti-CD3 antibody: a phase I/ II study. Clin Cancer Res. 2007; 13:3899-905. 